\title{
Effect of Phosphorus, PSB and Pressmud on Total Phophorus in Soil, Fertilizer Use Efficiency and Yield of Urd Bean
}

\author{
Ashutosh Singh* and Amit Kumar Pandey \\ Department of Soil Science and Agricultural Chemistry, Bihar Agricultural University, \\ Sabour-813210, Bhagalpur (Bihar), India \\ *Corresponding author
}

\section{A B S T R A C T}

\section{Keywords}

Total phosphors, Yield, Fertilizer use efficiency, PSB and pressmud urd bean.

\section{Article Info}

Accepted:

17 September 2017 Available Online:

10 October 2017
A field experiment was conducted during summer season of 2005 at Student Instructional Farm of Narendra Deva University of Agriculture and Technology, Kumarganj, Faizabad (U.P.). Three phosphorus levels (20, 40 and $\left.60 \mathrm{~kg} \mathrm{ha}^{-1}\right)$ with and without PSB or pressmud $\left(5 \mathrm{t} \mathrm{ha}^{-1}\right)$ were tested in a field investigation on total phosphorus in soil at harvest, fertilizer use efficiency and yield of urd bean. Results revealed that $60 \mathrm{~kg} \mathrm{P}_{2} \mathrm{O}_{5}$ along with pressmud $5 \mathrm{t} \mathrm{ha}^{-1}$ significantly increased the grain and straw yield. A considerable improvement in buildup of total $p$ in soil was observed under all treatments except control, alone PSB and pressmud. Buildup of phosphorus in terms of total phosphorus was significantly highest under 60 $\mathrm{kg} \mathrm{P}_{2} \mathrm{O}_{5} \mathrm{ha}^{-1}+$ pressmud and $60 \mathrm{~kg} \mathrm{P}_{2} \mathrm{O}_{5} \mathrm{ha}^{-1}$.

\section{Introduction}

In Indian agriculture pulses cultivation occupies an important place. The productivity of pulses is usually low because of their cultivation on marginal lands lacking in microbes in rhizosphere. Urd bean is one of the major pulse crop of India but has poor productivity recorded in different parts of the country. Interest in this crop, its multiple use as source of food, livestock fodder and soil fertilization.

Phosphorus is the second most critical plant nutrient over all, but for legumes it assumes primary importance. The soil of IndoGangetic Plain is generally low to medium in available phosphorus content and therefore, application of 17-26 kg $\mathrm{P} \mathrm{ha}{ }^{-1}$ has shown favourable effects in grain legumes (Ahlawat and Ali, 1993). Pressmud is one of the cheapest sources of organic fertilizer which is a byproduct of sugarcane industry. It contains $20-30 \%$ organic matter, $0.94-1.3 \%$ nitrogen, $1.66-2.74 \%$ phosphorus, 0.46-0.89\% potassium, 3.11-4.13\% $\mathrm{CaO}, 2.38 \% \mathrm{MgO}$ and $1.7 \% \mathrm{Fe}_{2} \mathrm{O}_{2}$ and $\mathrm{Al}_{2} \mathrm{O}_{3}$ (Raman et al., 1999).

Use of the organic fertilizers like pressmud and phosphorus solubilizing biofertilizer to certain extent can provide the required nutrient for optimum growth and productivity. 
Considering the advantages of phosphorus, PSB and pressmud the studies were undertaken to investigate the effect of phosphorus, PSB and pressmud on total phosphorus in soil, fertilizer use efficiency and yield of urd bean.

\section{Materials and Methods}

A field experiment was conducted during summer season 2005 at Student Instructional Farm of Narendra Deva University of Agriculture and Technology, Kumarganj, Faizabad (U.P.). The soil was silty loam having organic carbon $0.45 \%$, available $\mathrm{N}$ $262.0 \mathrm{~kg} \mathrm{ha}^{-1}$, available $\mathrm{P}_{2} \mathrm{O}_{5} 19.65 \mathrm{~kg} \mathrm{ha}^{-1}$, available $\mathrm{K}_{2} \mathrm{O} 272.80 \mathrm{~kg} \mathrm{ha}^{-1}$ and total $\mathrm{P}_{2} \mathrm{O}_{5}$ $385 \mathrm{~kg} \mathrm{ha}^{-1}$ with $\mathrm{pH}$ 8.1. Twelve treatments viz., control without $\mathrm{P}\left(\mathrm{T}_{1}\right), 20 \mathrm{~kg} \mathrm{P}_{2} \mathrm{O}_{5} \mathrm{ha}^{-1}$ $\left(\mathrm{T}_{2}\right), 40 \mathrm{~kg} \mathrm{P}_{2} \mathrm{O}_{5} \mathrm{ha}^{-1}\left(\mathrm{~T}_{3}\right), 60 \mathrm{~kg} \mathrm{P}_{2} \mathrm{O}_{5} \mathrm{ha}^{-1}$ $\left(\mathrm{T}_{4}\right), \mathrm{PSB}$ alone $\left(\mathrm{T}_{5}\right), 20 \mathrm{~kg} \mathrm{P}_{2} \mathrm{O}_{5} \mathrm{ha}^{-1}+\mathrm{PSB}$ $\left(\mathrm{T}_{6}\right), 40 \mathrm{~kg} \mathrm{P}_{2} \mathrm{O}_{5} \mathrm{ha}^{-1}+\mathrm{PSB}\left(\mathrm{T}_{7}\right), 60 \mathrm{~kg} \mathrm{P}_{2} \mathrm{O}_{5}$ $\mathrm{ha}^{-1}+\mathrm{PSB}\left(\mathrm{T}_{8}\right)$, pressmud (PM) alone $5 \mathrm{t} \mathrm{ha}^{-1}$ $\left(\mathrm{T}_{9}\right), 20 \mathrm{~kg} \mathrm{P} \mathrm{P}_{5} \mathrm{O}_{5} \mathrm{ha}^{-1}+5 \mathrm{t} \mathrm{PM}\left(\mathrm{T}_{10}\right), 40 \mathrm{~kg}$ $\mathrm{P}_{2} \mathrm{O}_{5} \mathrm{ha}^{-1}+5 \mathrm{t} \mathrm{PM}\left(\mathrm{T}_{11}\right)$ and $60 \mathrm{~kg} \mathrm{P}_{2} \mathrm{O}_{5} \mathrm{ha}^{-1}$ $+5 \mathrm{t}$ PM $\left(\mathrm{T}_{12}\right)$ were replicated thrice in a randomized block design. A uniform dose of $20 \mathrm{~kg} \mathrm{~N}$ and $40 \mathrm{~kg} \mathrm{~K}_{2} \mathrm{O} \mathrm{ha}^{-1}$ was applied in all the treatments. Pressmud was incorporated in soil and PSB was used for inoculating the seed as treatment @ $25 \mathrm{~g} \mathrm{~kg}^{-1}$ seed. 'Type-9' urd bean was sown in the last week of March. Other management practices were adopted as per recommendations of the crop. Total phosphorus content in soil was estimated by standard procedure (Jackson, 1973). Fertilizer use efficiency was computed as described by (Yoshida, 1978).

\section{Results and Discussion}

\section{Grain and straw yield}

Data in respect of grain and straw yield are presented in table 1. Seed yield of urd bean increased with increasing phosphorus upto 60 $\mathrm{kg} \mathrm{P}_{2} \mathrm{O}_{5} \mathrm{ha}^{-1}$ but difference in yield between $40 \mathrm{~kg} \mathrm{P}_{2} \mathrm{O}_{5}$ and $60 \mathrm{~kg} \mathrm{P}_{2} \mathrm{O}_{5}$ was not upto the level of significance. Inoculation of PSB did not improve the grain yield significantly while incorporation of pressmud enhanced the yield significantly at $20 \mathrm{~kg} \mathrm{P}_{2} \mathrm{O}_{5} \mathrm{ha}^{-1}$ having $12.6 \%$ additional yield. Among P solubilizing materials, pressmud was found to be slightly superior over PSB.

The highest increase in grain yield with $60 \mathrm{~kg}$ $\mathrm{P}_{2} \mathrm{O}_{5} \mathrm{ha}^{-1}+$ pressmud might be because of association with enhancement in yield attributing characters such as pods per plant and grains per pod (Patel and Thakur, 2003). Similar trend was observed for straw yield.

\section{Harvest index (\%)}

Data on harvest index are summarized in table 1. It is obvious from data that lowest value (31.85\%) was found in control plot receiving no $\mathrm{P}$ fertilizer while highest value $(34.72 \%)$ was computed under treatment $\mathrm{T}_{12}$ receiving $60 \mathrm{~kg} \mathrm{P}_{2} \mathrm{O}_{5}$ ha $^{-1}$ with PM.

Harvest index of urd bean increased with increasing levels of phosphorus having $33.15 \%, 34.02 \%$ and $34.47 \%$ under $\mathrm{P}_{20}, \mathrm{P}_{40}$ and $\mathrm{P}_{60}$, respectively, however differences were not upto the level of significance.

\section{Test Weight (g)}

The data regarding test weight of grains of urd bean are furnished in table 1 . Test weight increased with increasing levels of phosphorus upto $60 \mathrm{~kg}_{2} \mathrm{O}_{5}$ ha $^{-1}$ having $33.89,35.62$ and 36.86 under $\mathrm{P}_{20}, \mathrm{P}_{40}$ and $\mathrm{P}_{60}$, respectively but differences were not upto the level of significance.

However, $\mathrm{P}_{60}+\mathrm{PSB}$ and $\mathrm{P}_{60}+\mathrm{PM}$ were found slightly superior over the control and rest of the treatments. The trend was similar to these observed by Singh et al., (2003). 
Table.1 Effect of phosphorus, PSB and pressmud on yield, harvest index and test weight

\begin{tabular}{|c|c|c|c|c|}
\hline \multirow[t]{2}{*}{ Treatment } & \multicolumn{2}{|c|}{ Yield $\left(q\right.$ ha $\left.^{-1}\right)$} & \multirow{2}{*}{$\begin{array}{c}\text { Harvest } \\
\text { Index }(\%)\end{array}$} & \multirow{2}{*}{$\begin{array}{c}\text { Test } \\
\text { Weight (g) }\end{array}$} \\
\hline & Grain & Straw & & \\
\hline$T_{1}$-Control & 7.10 & 15.19 & 31.85 & 31.59 \\
\hline $\mathrm{T}_{2^{-}} 20 \mathrm{Kg} \mathrm{P}_{2} \mathrm{O}_{5} \mathrm{ha}^{-1}\left(\mathrm{P}_{20}\right)$ & 10.03 & 20.22 & 33.15 & 33.89 \\
\hline $\mathrm{T}_{3}-40 \mathrm{Kg} \mathrm{P}_{2} \mathrm{O}_{5} \mathrm{ha}^{-1}\left(\mathrm{P}_{40}\right)$ & 11.62 & 22.53 & 34.02 & 35.62 \\
\hline $\mathrm{T}_{4}-60 \mathrm{Kg} \mathrm{P}_{2} \mathrm{O}_{5} \mathrm{ha}^{-1}\left(\mathrm{P}_{60}\right)$ & 12.45 & 23.67 & 34.47 & 36.86 \\
\hline$T_{5}$-PSB alone & 7.85 & 16.41 & 32.36 & 33.03 \\
\hline $\mathrm{T}_{6}-20 \mathrm{Kg} \mathrm{P}_{2} \mathrm{O}_{5} \mathrm{ha}^{-1}+\mathrm{PSB}$ & 10.90 & 21.85 & 33.30 & 34.73 \\
\hline $\mathrm{T}_{7}-40 \mathrm{Kg} \mathrm{P}_{2} \mathrm{O}_{5} \mathrm{ha}^{-1}+\mathrm{PSB}$ & 12.04 & 23.19 & 34.14 & 36.58 \\
\hline $\mathrm{T}_{8^{-}} 60 \mathrm{Kg} \mathrm{P}_{2} \mathrm{O}_{5} \mathrm{ha}^{-1}+\mathrm{PSB}$ & 13.01 & 24.59 & 34.60 & 37.34 \\
\hline $\mathrm{T}_{9^{-}}$Pressmud alone $(\mathrm{PM})\left[5 \mathrm{t} \mathrm{ha}^{-1}\right]$ & 8.07 & 16.62 & 32.69 & 33.67 \\
\hline $\mathrm{T}_{10^{-}} 20 \mathrm{Kg} \mathrm{P}_{2} \mathrm{O}_{5} \mathrm{ha}^{-1}+5 \mathrm{t}_{\text {pressmud }} \mathrm{ha}^{-1}$ & 11.30 & 22.48 & 33.45 & 35.22 \\
\hline $\mathrm{T}_{11^{-}} 40 \mathrm{Kg} \mathrm{P}_{2} \mathrm{O}_{5} \mathrm{ha}^{-1}+5 \mathrm{t}$ pressmud ha $^{-1}$ & 12.11 & 23.23 & 34.30 & 36.61 \\
\hline $\mathrm{T}_{12^{-}} 60 \mathrm{Kg} \mathrm{P}_{2} \mathrm{O}_{5} \mathrm{ha}^{-1}+5 \mathrm{t}$ pressmud ha $^{-1}$ & 13.16 & 24.74 & 34.72 & 37.80 \\
\hline SEm \pm & 0.35 & 0.72 & 0.66 & 1.66 \\
\hline C.D. (0.05) & 1.03 & 2.11 & NS & NS \\
\hline
\end{tabular}

Table.2 Effect of phosphorus, PSB and pressmud on total phosphorus in soil after harvest and fertilizer use effecincy

\begin{tabular}{|c|c|c|c|}
\hline Treatment & $\begin{array}{c}\text { Total phosphorus } \\
\text { in soil } \\
\left(\mathrm{kg} \mathrm{P}_{\mathbf{2}} \mathrm{O}_{5} \mathrm{ha}^{-1}\right)\end{array}$ & $\begin{array}{c}\text { Depletion or } \\
\text { buildup over } \\
\text { initial P status } \\
\left(\mathrm{kg} \mathrm{ha}^{-1}\right)\end{array}$ & $\begin{array}{l}\text { Fertilizer } \\
\text { use } \\
\text { efficiency }\end{array}$ \\
\hline $\mathbf{T}_{1}$-Control & 378 & -7 & - \\
\hline $\mathrm{T}_{2^{-}} 20 \mathrm{Kg} \mathrm{P}_{2} \mathrm{O}_{5} \mathrm{ha}^{-1}\left(\mathbf{P}_{20}\right)$ & 393 & +8 & 14.65 \\
\hline $\mathrm{T}_{3^{-}}-40 \mathrm{Kg} \mathrm{P}_{2} \mathrm{O}_{5} \mathrm{ha}^{-1}\left(\mathrm{P}_{40}\right)$ & 408 & +23 & 11.30 \\
\hline $\mathrm{T}_{4}-60 \mathrm{Kg} \mathrm{P}_{2} \mathrm{O}_{5} \mathrm{ha}^{-1}\left(\mathrm{P}_{60}\right)$ & 427 & +42 & 8.92 \\
\hline $\mathrm{T}_{5}$-PSB alone & 376 & -9 & - \\
\hline $\mathrm{T}_{6}-20 \mathrm{Kg} \mathrm{P}_{2} \mathrm{O}_{5} \mathrm{ha}^{-1}+\mathrm{PSB}$ & 391 & +6 & 19.00 \\
\hline $\mathrm{T}_{7}=40 \mathrm{Kg} \mathrm{P}_{2} \mathrm{O}_{5} \mathrm{ha}^{-1}+\mathrm{PSB}$ & 407 & +22 & 12.35 \\
\hline $\mathrm{T}_{8}-60 \mathrm{Kg} \mathrm{P}_{2} \mathrm{O}_{5} \mathrm{ha}^{-1}+\mathrm{PSB}$ & 425 & +40 & 9.85 \\
\hline 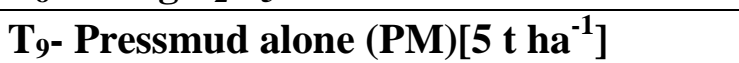 & 378 & -7 & - \\
\hline $\mathrm{T}_{10^{-}} 20 \mathrm{Kg} \mathrm{P}_{2} \mathrm{O}_{5} \mathrm{ha}^{-1}+5 \mathrm{t}_{\text {pressmud ha }}{ }^{-1}$ & 392 & +7 & 21.00 \\
\hline $\mathrm{T}_{11^{-}} 40 \mathrm{Kg} \mathrm{P}_{2} \mathrm{O}_{5} \mathrm{ha}^{-1}+5 \mathrm{t}$ pressmud ha ${ }^{-1}$ & 409 & +24 & 12.53 \\
\hline $\mathrm{T}_{12^{-}} 60 \mathrm{Kg} \mathrm{P}_{2} \mathrm{O}_{5} \mathrm{ha}^{-1}+5 \mathrm{t}$ pressmud ha ${ }^{-1}$ & 427 & +42 & 10.10 \\
\hline $\mathrm{SEm} \pm$ & 7.26 & - & - \\
\hline C.D. (0.05) & 21.40 & - & - \\
\hline
\end{tabular}


Fig.1 Depletion or buildup over initial P status in soil as affected by phosphorus, PSB and pressmud at harvest

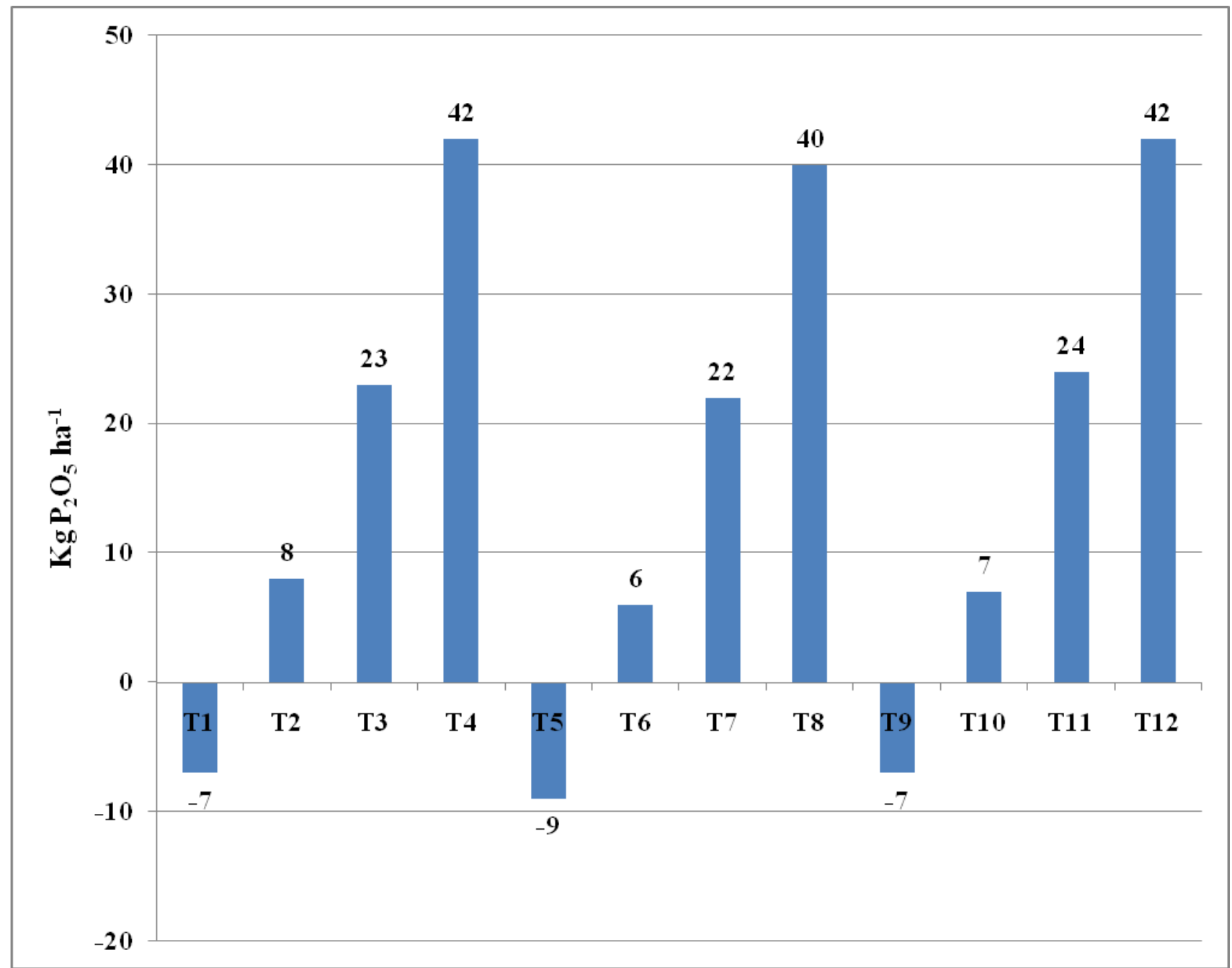

\section{Total phosphorus in soil}

Data on total phosphorus content in soil at harvest are presented in table 2 and depicted in figure 1. The total phosphorus in soil found depleted in control receiving neither $\mathrm{P}$ nor solubilizing agents. Similarly, alone application of PSB and pressmud also showed depletion in total $\mathrm{P}$ content with a tune of 9 and $7 \mathrm{~kg} \mathrm{ha}^{-1}$, respectively over initial status. All other treatments containing phosphorus found to be improved total $\mathrm{P}$ status of soil. The buildup of total phosphorus increased with increasing level of $\mathrm{P}$ upto $60 \mathrm{~kg} \mathrm{P}_{2} \mathrm{O}_{5}$ ha ${ }^{1}$ either alone or inoculation with PSB or PM.

\section{Fertilizer use efficiency}

The data are presented in table 2 with respect to fertilizer use efficiency in terms of $\mathrm{kg}$ grains $/ \mathrm{kg} \mathrm{P}_{2} \mathrm{O}_{5} \mathrm{ha}^{-1}$. It is interesting to note that fertilizer use efficiency increased with decreasing levels of $\mathrm{P}$.

This tendency was noticed with alone application of $\mathrm{P}$ as well as inoculation of PSB or incorporation of PM with different levels of P. Incorporation of pressmud along with phosphorus found to be more effective in improving the apparent recovery of applied $\mathrm{P}$ fertilizer as compare to PSB having 21.00, 
12.53 and 10.10 fertilizer use efficiency with $\mathrm{P}_{20}+\mathrm{PM}, \mathrm{P}_{40}+\mathrm{PM}$ and $\mathrm{P}_{60}+\mathrm{PM}$, respectively.

\section{Acknowledgement}

Author is grateful to Dr. Room Singh University Professor, Director Seed \& Farm and Dr. L.P. Verma, Associate Professor and Dr. P. N. Tripathi, Associate Professor, for their help and guidance.

\section{References}

Ahlawat, I.P.S., and Ali, M. 1993. Fertilizer management in pulses. In: Fertilizer management in food crops. India: Fertilizer Development and Consultation Organization pp. 33-44. Jackson, M.L., 1973. Soil chemical analysis.
Prentice Hall of India, Pvt. Ltd. New Delhi.

Patel, S.R., and Thakur, D.S. 2003. Response of black gram (Phaseolus mungo) to levels of phosphorus and phosphate solubilizing bacteria. Annals of Agricultural Research24 (4): 819-823.

Raman, S., Patil, R.G. and Zalawadia, N.M. 1999. Pressmud as a potential source of nutrients, amendment and wax. Fertilizer News44 (11): 25-26, 29-31.

Singh, Bharat, Singh, C.P., and Singh, Manish 2003. Response of summer moong (Vigna radiata L.) to levels of phosphorus and PSM inoculation in sandy loam soil. Annals of Agricultural Research24 (4): 860-866.

Yoshida, S., 1978. Fundamental of rice crop production. IRRI Manila p126.

\section{How to cite this article:}

Ashutosh Singh and Amit Kumar Pandey. 2017. Effect of Phosphorus, PSB and Pressmud on Total Phophorus in Soil, Fertilizer Use Efficiency and Yield of Urd Bean. Int.J.Curr.Microbiol.App.Sci. 6(10): 1775-1779. doi: https://doi.org/10.20546/ijcmas.2017.610.214 